\title{
Zpěněná moč
}

\section{prof. MUDr. Zdeněk Doležel, CSc., MUDr. Jan Papež, MUDr. Dana Dostálková Pediatrická klinika LF MU a FN Brno}

\section{Klíčová slova: zpěněná moč, proteinurie, nefropatie.}

\section{Key words: foamy urine, proteinuria, nephropathy.}

U 9letého chlapce došlo bez zřetelné vyvolávající prríčiny k manifestaci otoků, které byly dominantně vyjádřeny periorbitálně a na dolních končetinách (dorzum nohou, bérce), dále byl prokázán ascites, edém genitálu nebyl prítomen. Klinická symptomatologie ve spojení s abnormálními výsledky laboratorních vyšetření (hypalbuminémie $21 \mathrm{~g} / \mathrm{l}$, hypercholesterolémie $8,3 \mathrm{mmol} / \mathrm{l}$, proteinurie $2860 \mathrm{mg} / 24 \mathrm{~h}$ ) umožnily stanovit diagnózu primárního nefrotického syndromu (NS). Léčba byla zahájena kortikoidy - prednison prvních 6 týdnů v dávce $60 \mathrm{mg} / \mathrm{m}^{2}$, dalších 6 týdnů v dávce $40 \mathrm{mg} / \mathrm{m}^{2}$. Kortikoterapii hoch dobře toleroval a po dosažení klinické a laboratorní remise NS bylo podávání kortikoidů ukončeno. S odstupem 4 měsíců, v průběhu zimního pobytu na horách, si matka náhodně všimla, že chlapcova moč zůstala v toaletě více zpěněná. S prìhlédnutím k dosavadním zkušenostem z domácího sledování vyšetřila matka moč testačními proužky s nálezem proteinurie 3+. Při následném klinickém vyšetření měl chlapec nevýrazné symetrické otoky nártů a perimaleolárně. Makroskopicky byla moč ve sběrné nádobce zpěněná (obrázek 1 a 2). Výsledky laboratorních vyšetření prokázaly relaps NS, proteinurie byla 3560 mg/24 h. Vzhledem ke steroid-senzitivní odpovědi na iniciální léčbu NS byly v terapii relapsu použity znovu kortikoidy a po dosažení remise zůstávala moč bez zřetelné vizuální abnormity (obrázek 3).
Za fyziologických okolností dochází ke zpěnění moči nejčastěji v souvislosti s rychlou a relativně objemnou mikcí. Za této situace je tvorba pěny na moči dobře viditelná zejména při močení na toaletě nebo močení do vany, pritom však již obvykle ke konci mikce či velmi krátce po ní není pěna tak zřetelná a rychle ustupuje. Nejčastější prričinou zpěněné moči, kdy i po několik minut od ukončení močení stále přetrvává na moči pěna, je proteinurie. Zvýšené množství bílkoviny v moči snižuje její povrchové napětí a to je fyzikálním podkladem této makroskopické změny. Pomineme-li príčiny patologické proteinurie, je ojediněle zpěněná moč popisována také u jedinců, kterí požili stravu s vysokým obsahem bílkovin. $\checkmark$ těchto prípadech však zpěněná moč bývá pouze $v$ jedné nebo maximálně dvou mikcích, které po takovém excesivním príimu proteinů následují. Raritními příčinami zpěněné moči bývají bakteriální nebo mykotické infekce močových cest, při kterých však moč bývá navíc obvykle zkalená a zapáchá. Jsou-li někteři pacienti s prokázanou nefropatií poučeni o fenoménu „zpěněná moč“, mohou si sami všimnout, že k této změně dochází prì relapsu/progresi jejich ledvinné choroby a včasně vyhledají lékaře. Obecně však spíše platí, a to zejména u dětí, že abnormálně napěněná moč uniká pozornosti jak močícího subjektu, tak i jeho okolí.

Podpořeno MZČR-RVO (FNBr 65269705)
Obr. 1. Za 3 min po vymočení; proteinurie 3560 mg/24h

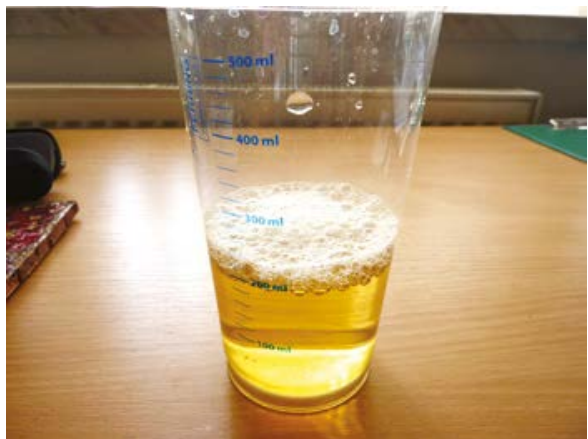

Obr. 2. Za 10 min po vymočení; proteinurie $3560 \mathrm{mg} / 24 \mathrm{~h}$

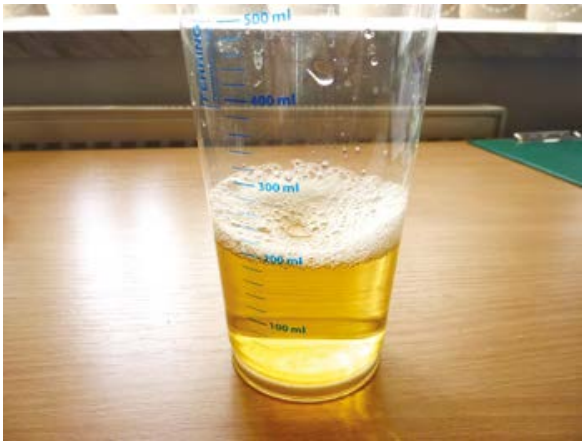

Obr. 3. Za 3 min po vymočení; proteinurie $187 \mathrm{mg} / 24 \mathrm{~h}$

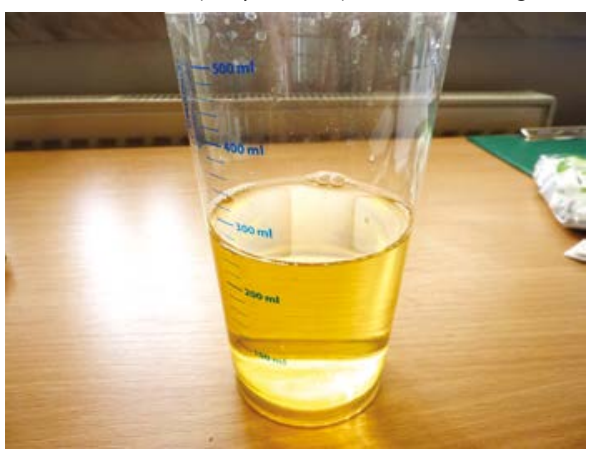
KORESPONDENČNII ADRESA AUTORA: prof. MUDr. Zdeněk Doležel, CSc., zdoleze@fnbrno.czＣit. zkr: Pediatr. praxi. 2016; 17(2): 104 Pediatrická klinika LF MU a FN Brno Černopolní 9, 62500 Brno 